\title{
Photovoltaic Cell Temperature Estimation for a Grid-Connect Photovoltaic Systems in Curitiba
}

\author{
Renata Lautert Yang ${ }^{1 *}$ \\ https://orcid.org/0000-0002-1867-229X
}

Gerson Máximo Tiepolo²

https://orcid.org/ 0000-0002-0409-4484

\section{Édwin Augusto Tonolo ${ }^{1}$}

https://orcid.org/0000-0002-8644-650X

Jair Urbanetz Junior ${ }^{1}$

https://orcid.org/ 0000-0001-9355-1730

Muriele Bester de Souza ${ }^{1}$

https://orcid.org/0000-0002-4510-5207

1 Universidade Tecnológica Federal do Paraná - Postgraduate Program in Energy Systems (PPGSE), Solar Energy Laboratory (LABENS), Curitiba, Paraná, Brazil; ${ }^{2}$ Universidade Tecnológica Federal do Paraná - Academic Department of Electrical Engineering (DAELT), Solar Energy Laboratory (LABENS), Curitiba, Paraná, Brazil

Received: 2018.11.05; Accepted: 2019.07.29.

* Correspondence: relautert@gmail.com; Tel.: +55-41-996950786 (R.L.Y.)

\section{HIGHLIGHTS}

- Photovoltaic solar energy has exponentially increased its installed capacity.

- Solar radiation raises the temperature in photovoltaic cells $(T c)$, generating losses.

- Several equations were elaborated to estimate the Tc.

- For Curitiba, the best Tc equation was proposed by Duffie and Beckman.

\begin{abstract}
The photovoltaic solar energy has been growing in installed capacity worldwide year by year, and Brazil has also been investing in this renewable source of energy generation. The conversion of light into electrical energy occurs in the photovoltaic cells, which are sensitive to the increase of the temperature. A considerable amount of the energy incident on the module is transformed into heat, rising its temperature and decreasing its efficiency. This study aims to estimate the temperature in photovoltaic cells $(T C)$ for polycrystalline silicon modules from a grid-connected photovoltaic systems through several
\end{abstract}


equations proposed over the last decades by researchers. This estimation will occur in the municipality of Curitiba, using data from INMET's automatic station, located in the same city. The estimation was calculated hourly, throughout the day for one year. The validation of the estimated results was performed by measuring the cell temperature of a photovoltaic system installed in Curitiba, where it was observed that the equation proposed by Duffie and Beckman (2013) was the one that most approached to the measured value.

Keywords: Photovoltaic solar energy; grid-connected photovoltaic system; estimation of the photovoltaic cell temperature.

\section{INTRODUCTION}

The luminous energy from the Sun can be utilized through the photovoltaic effect to generate electricity, which is named as photovoltaic solar energy [1]. Between 2016 and 2017, it was the world's largest growing renewable energy source, with a cumulative installed capacity of $402 \mathrm{GW}$ by the end of 2017 [2] [3]. In the Brazilian scenario, installed capacity has also been increased significantly year by year [4] [5]. The State of Paraná has a significant photovoltaic potential in the national composition, and it's far superior when compared with many countries in Europe. This information shows, in general, how much the application of this technology has grown, as well as the potential to be explored in Paraná. In this way, getting to know the technologies and the factors that affect their productivity become more important.

The photovoltaic modules are constituted of photovoltaic cells, which are built from semiconductor materials, converting the energy coming from the Sun into electric energy. Therefore, the cells are sensible to the temperature. The efficiency of the modules is measured and informed to the users through the datasheet, under standard test conditions (STC), with temperature of $25^{\circ} \mathrm{C}$, irradiance of $1,000 \mathrm{~W} / \mathrm{m}^{2}$ and air mass (AM) of 1.5 , yet a photovoltaic system rarely operates under these conditions [6] [7]. The performance is mainly influenced by the used technology. A typical photovoltaic (PV) module converts between $6 \%$ to $20 \%$ of the incident solar radiation into electrical energy, depending on the type of the solar cell technology and the climatic conditions. The remainder of the incident solar radiation is converted into heat, which increases significantly the temperature of the PV module and reduces its efficiency [8]. The temperature of a photovoltaic module depends on some climatic factors, such as incident solar radiation, ambient temperature, wind speed and direction, physical properties of the cell materials and assembly structure [9].

During the day, the irradiance varies more than the temperature. Shifts in the irradiance affects essentially the output current of the module, since the current depends directly on the incident solar radiation, while the voltage of the module is affected mainly by the temperature of the module [7]. The temperature also affects the degradation of the PV modules, because it determines the reaction rate for the deterioration processes caused by other degradation factors, such as hydrolysis by humidity and photo-degradation by ultraviolet light [10].

For the majority of the photovoltaic installations, direct cell temperature measurements are not available. Therefore, it is desirable to parameterize the physical relationship between the photovoltaic cell temperature, the input irradiance and the relevant meteorological parameters [6]. This research aims to analyze nine existing models of calculations to estimate the temperature in the photovoltaic cells $(T c)$ proposed over the last decades by researchers, whose final objective is to verify which equation is closer to the real measured values. This analysis and validation will take place in Curitiba, through a grid-connected photovoltaic system installed in the Green Office (GO) of the Federal University of Technology - Paraná (UTFPR). 


\section{MATERIAL AND METHODS}

Analyzing the models for calculating the temperature of the photovoltaic cell, nine cited in the international literature equations were studied, which depends on several parameters. The temperature at any point in the PV module is assumed to be constant within this short time interval. The nominal operating cell temperature (NOCT) represents an indication of the PV module temperature and it is supplied by its manufacturer, and this value is acquired according to the parameters provided by the standard reference environment (SRE), which determines the inclination of the module equal to the local latitude, total irradiance (GNOCT) of $800 \mathrm{~W} / \mathrm{m}^{2}$, ambient temperature ( $\mathrm{Ta}$ ) equal to $20^{\circ} \mathrm{C}$, wind speed $(\mathrm{Vw})$ of $1 \mathrm{~m} / \mathrm{s}$ and zero electric charge [11]. The models are based on the fact that the difference between the module temperature and the ambient temperature is independent of the air temperature, however it is directly proportional to the irradiance if the on-site conditions are fixed. In order to perform the temperature in the photovoltaic cells $(T c)$ measurement, it was considered that this temperature is approximately equal to the temperature at the back of the PV module, if its enclosure is thin and has a low thermal resistance. The temperature dependent parameters of the PV cell and used in these calculations are described in Table 1, according to [12].

Table 1. Parameters description.

\begin{tabular}{cc}
\hline Parameter & Description \\
\hline $\mathrm{Ta}$ & Ambient temperature in ${ }^{\circ} \mathrm{C}$ \\
$\mathrm{G}$ & Total irradiance in $\mathrm{W} / \mathrm{m}^{2}$ \\
$\mathrm{~T} \mathrm{C}_{\mathrm{NOCT}}$ & Cell nominal operating temperature, provided by the \\
$\mathrm{Ta}_{\text {NOCT }}$ & manufacturer of the photovoltaic module, in ${ }^{\circ} \mathrm{C}$ \\
$\mathrm{G}_{\text {NOCT }}$ & Ambient temperature according to $\mathrm{SRE}$, set at $20^{\circ} \mathrm{C}$ \\
$\mathrm{Vw}$ & Total irradiance according to SRE, set at $800 \mathrm{~W} / \mathrm{m}^{2}$ \\
$\alpha$ & Wind speed in $\mathrm{m} / \mathrm{s}$ \\
$\beta$ & Constant equal to 0.0138 \\
$\gamma$ & Constant equal to 0.031 \\
$\eta_{\mathrm{c}}$ & Constant equal to 0.042 \\
$\tau \alpha$ & Conversion efficiency of the module described in its \\
$\eta_{\mathrm{m}}$ & datasheet \\
\hline
\end{tabular}

The equation for Tc proposed by [13] uses an "installation mode coefficient" $(\omega)$ of the PV module, which is dimensionless and varies according to the installation form of these modules, being directly proportional to $T c$, as shows in Table 2 .

Table 2. Installation mode coefficient.

\begin{tabular}{cc}
\hline PV installation mode & $\boldsymbol{\omega}$ \\
\hline Free installation & 1 \\
On the roof, with ventilation & 1.2 \\
On the roof, without ventilation & 1.8 \\
Integrated to the facade & 2.4 \\
\hline Coefficient for different installation modes [13].
\end{tabular}

In this study, the equations used for Tc's calculation are explicit and are described in the sequence, with each author, named from Tc 1 to Tc 9 . All the equations were used in the simulations for the city of Curitiba, covering a time period of one year with hourly data of 
the variable parameters, obtained through the INMET (National Meteorological Institute) database.

Tc 1 - Rauschenbach [14]:

$$
T c=T a+\left(\frac{G}{G_{N O C T}}\right) \cdot\left(T c_{N O C T}-T a_{N O C T}\right) \cdot\left(1-\frac{\eta m}{(\tau \alpha)}\right)
$$

Tc 2 - Risser and Fuentes [15]:

$$
T c=3,81+0,0282 \cdot G+1,31 \cdot T a-1,65 V w
$$

Tc 3 - Ross and Smokler [16]:

$$
T c=T a+\frac{\left(T c_{N O C T}-T a_{N O C T}\right)}{G_{N O C T}} \cdot G
$$

Tc 4 - Schott [17]:

$$
T c=T a+0,028 \cdot G-1
$$

Tc 5 - Servant [18]:

$$
T c=T a+\alpha G(1+\beta T a)(1-\gamma V w)(1-1,053 \eta m)
$$

Tc 6 - Lasnier and Ang [19]:

$$
T c=30,006+0,0175(G-300)+1,14(T a-25)
$$

Tc 7 - Chenni, Makhlouf, Kerbache and Bouzid [20]:

$$
T c=0,943 \cdot T a+0,028 . G-1,528 . V w+4,3
$$

Tc 8 - Skoplaki, Boudouvis and Palyvos [13]:

$$
T c=T a+\omega\left(\frac{0,32}{8,91+2,0 V w}\right) G
$$

Tc 9 - Duffie and Beckman [21]:

$$
T c=T a+\left[\left(\frac{G}{G_{N O C T}}\right) \cdot\left(\frac{9,5}{5,7+3,8 \cdot V w}\right) \cdot\left(T c_{N O C T}-T a_{N O C T}\right) \cdot\left(1-\frac{\eta c}{(\tau \alpha)}\right)\right]
$$

Tc's estimation will be performed for the city of Curitiba, involving only polycrystalline silicon (p-Si) technology used in the photovoltaic modules, considering that they are applied on the roof without ventilation. For the calculations, hourly data were collected from INMET meteorological automatic stations A-807, located in Curitiba, $3.9 \mathrm{~km}$ away from where the $\mathrm{PV}$ system is installed and where the validation of the obtained results occurred. The ambient temperature $(\mathrm{Ta})$ used in the calculations comprises the average between the maximum and minimum temperature, in degrees Celsius $\left({ }^{\circ} \mathrm{C}\right)$, the wind speed, in meters per second $(\mathrm{m} / \mathrm{s})$, were used in addition to the irradiation, which is provided in kilo Joule per square meter $\left(\mathrm{kJ} / \mathrm{m}^{2}\right)$ in a time interval of one hour, which were converted to watt-hour per square meter $\left(\mathrm{Wh} / \mathrm{m}^{2}\right)$. Finishing the calculations for Curitiba, experimental measurements of temperature of a PV module belonging to a grid-connected system installed in the Green Office (GO) of the Federal University of Technology - Paraná (UTFPR) were carried out in order to validate the obtained results, whose geographical coordinates are: latitude $25.440626 \mathrm{~S}$ and longitude $49.268196 \mathrm{~W}$. This system, according to [23], has $2.1 \mathrm{kWp}$ of $\mathrm{p}$ Si modules installed on the roof of the building. The measurements took place under the PV module, on June $11^{\text {th }} 2018$, hourly, between 8 am to $5 \mathrm{pm}$, and in this last time there was shading in the panel due to an adjacent building. The day weather was characterized as sunny, with few clouds. The instrument used for the measurements was an Icel MD-6110 multimeter, which was also used to measure Ta. 


\section{RESULTS AND DISCUSSION}

The results calculations of the nine equations are shown graphically. Differently from [24], which used only one equation to calculate the annual mean temperature in the photovoltaic cells $(T c)$ for Curitiba, and from it, estimated the yield of a PV module. The graphs presentation and discussions were divided by the seasons of winter and summer, in which the behavior of the Tc was analyzed. In this way, it was possible to observe its variation in a typical winter day, characterized by low temperatures and shorter day length, and also to a summer day, when temperatures are high and the length of the day is longer. In all analyzes, the night period, where the irradiance is zero, was disregarded during the calculations.

\section{Winter}

For the winter season, the premise for choosing the simulated day was that it presented repeated times during the day when the ambient temperature was equal or below to $10^{\circ} \mathrm{C}$. Thus, the chosen date to analyze $T c$ was June $20^{\text {th }}, 2017$. In Figure 1 is presented the results of the calculations of the nine proposed equations to find $T c$, with different colors. In black, can be observed the ambient temperature on this specific day, provided by INMET's station, and it is possible to relate its variation to the $T c$ behavior throughout the day. It is observed that the maximum $\mathrm{Ta}$ did not exceed $12^{\circ} \mathrm{C}$ in this simulation. It was noticed that $T c$, in practically all the hours and models, maintained its values above Ta. The model proposed by Lasnier and Ang (1990), Tc 6, presented Tc value lower than Ta in most of the time, due to two subtractions in its equation in which, due to the low temperature and low irradiation, it results in a $T c$ with low value in relation to $T a$.

Still analyzing Figure 1, we can see cuts in the Tc curves, demonstrating moments when the sky was cloudy. It was noticed that the curves for the nine methodologies presented similar formats throughout the day. In general, Tc 2 presented higher values, while Tc 6 showed lower values, comparatively. Differences were observed between the maximum calculated values of $T c$, with the highest $T c$ reaching $20^{\circ} \mathrm{C}$ in the model [15], while for [19] the maximum $T c$ did not exceed $14^{\circ} \mathrm{C}$. In addition, it was noticed that between 11 am to 3 pm the Tc obtained the highest values, in all the methodologies.

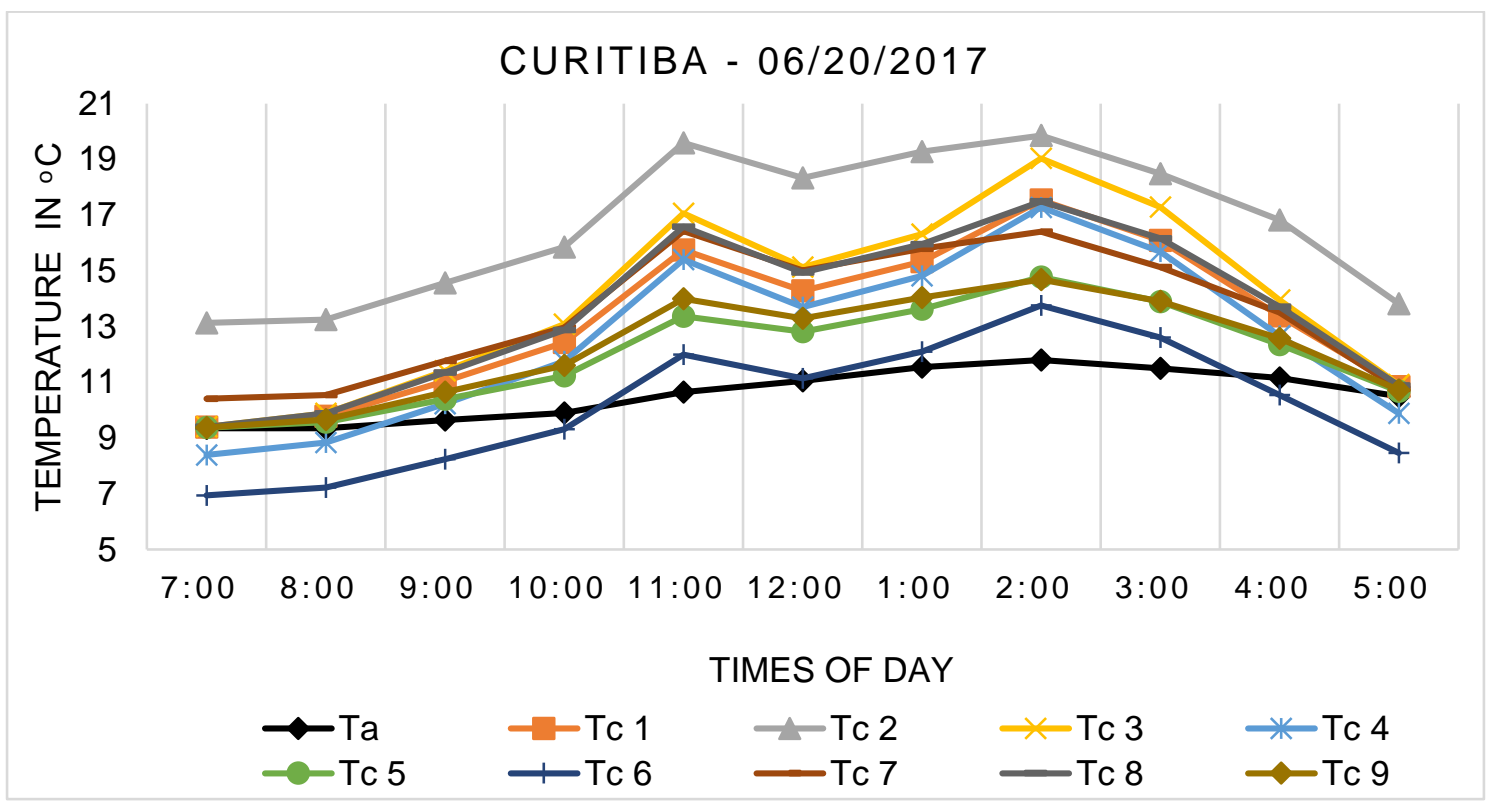

Figure 1. Ta and Tc calculated for Curitiba for the winter period. 


\section{Summer}

The data analyzed during the summer were selected on the premise that the mean ambient temperature, for repeated hours of the day, was equal to or greater than $25^{\circ} \mathrm{C}$. In this way, the graph was plotted with data referring to January $5^{\text {th }} 2018$. In Figure 2 is presented the simulated data for this summer date for Curitiba, showing the behavior of temperature in the photovoltaic cells $(T c)$ during the day according to nine different proposed calculations. The ambient temperature $(\mathrm{Ta})$, represented by the black curve, remained equal to or less than the $T c$ in all analyzed models, reaching values close to $30^{\circ} \mathrm{C}$.

The shape of the curves presents proportional behavior, with some variations, since each methodology assigns a different weight to the chosen parameters to compose the equation. Ta and irradiance are factors present in all the models studied, however they do not always act on $T c$ with the same weight. In addition to these elements, some equations also consider that the Tc depends on the wind speed, the technology used in the PV cell, module's installation mode and other constants, each one interfering differently in the TC.

The perceptible cut-offs in the curves of Figure 2 revealed the passage of clouds during the day, and the maximum $T c$ calculated was $66.4^{\circ} \mathrm{C}$, referring to the $T c 2$ equation at around $1 \mathrm{pm}$, where the maximum irradiance value is obtained. The lower temperatures for $T c$ were registered in the TC 5 and TC 6 simulations. As for the Tc variation in relation to $T a$, the largest difference between these values reached $39.4^{\circ} \mathrm{C}$ at $1 \mathrm{pm}$.

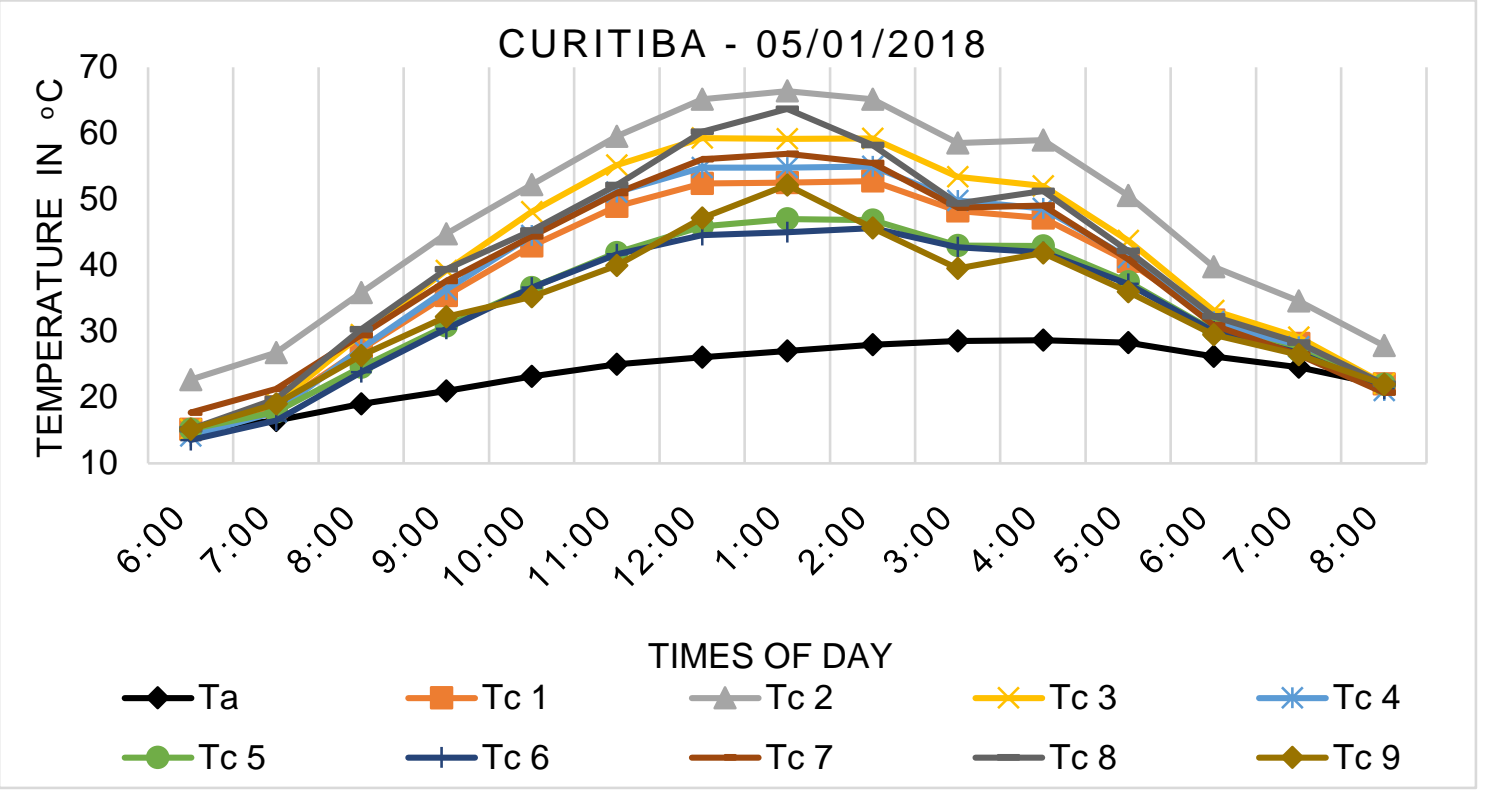

Figure 2. Ta and TC calculated for Curitiba for the summer period.

\section{Validation of results}

On June $11^{\text {th }}$ 2018, Ta and Tc measurements were performed hourly in a PV module of the Green Office (GO) in Curitiba. In Figure 3 is shown the GO [23] and the measurement performed at $1 \mathrm{pm}$, where the maximum temperature of the module was observed on this day, $35^{\circ} \mathrm{C}$. 


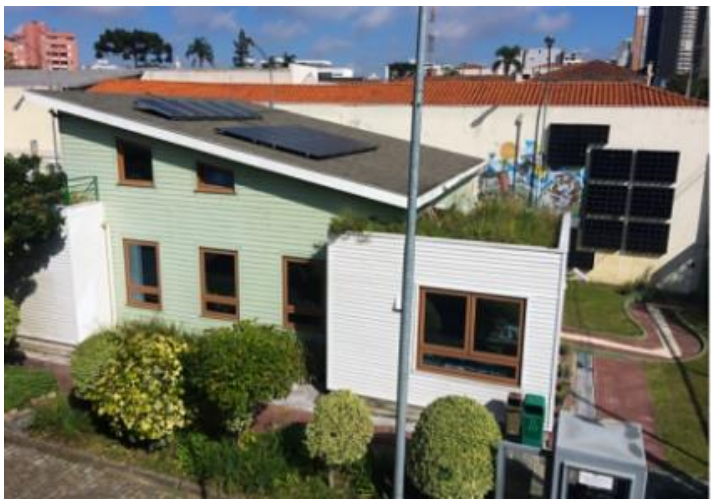

(a)

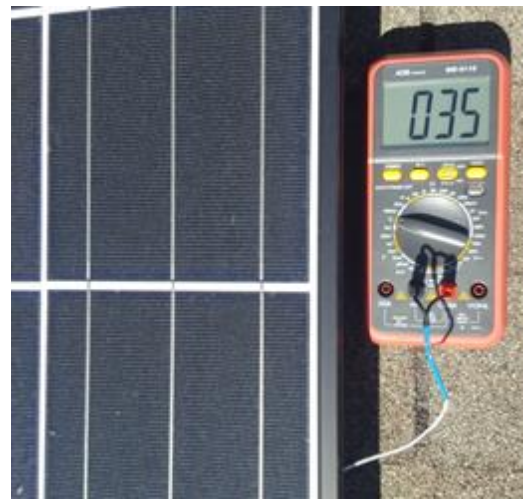

(b)

Figure 3. (a) Green Office; (b) Tc measurement at $1 \mathrm{pm}$.

The result of the measurements, the comparison with $\mathrm{Ta}$ and the calculated values for the nine Tc's equations are shown in Figure 4. The INMET's ambient temperature, $T a$, remained below the calculated values for $T c$ and higher than the Ta measured at all times. This fact is due to the quality of the multimeter, presenting suspicious data during the measurement, considering the difference between the values measured by it and the INMET A-807 station. The curves representing the nine calculation methodologies for the Tc present a similar format throughout the day, differing in the values during the simulation. The equation for $T c 2$ showed the highest temperatures during the day, reaching $46.6^{\circ} \mathrm{C}$ at $1 \mathrm{pm}$. On the other hand, the model for Tc 9 showed the lower values, reaching a maximum of $31.8^{\circ} \mathrm{C}$, at $1 \mathrm{pm}$.

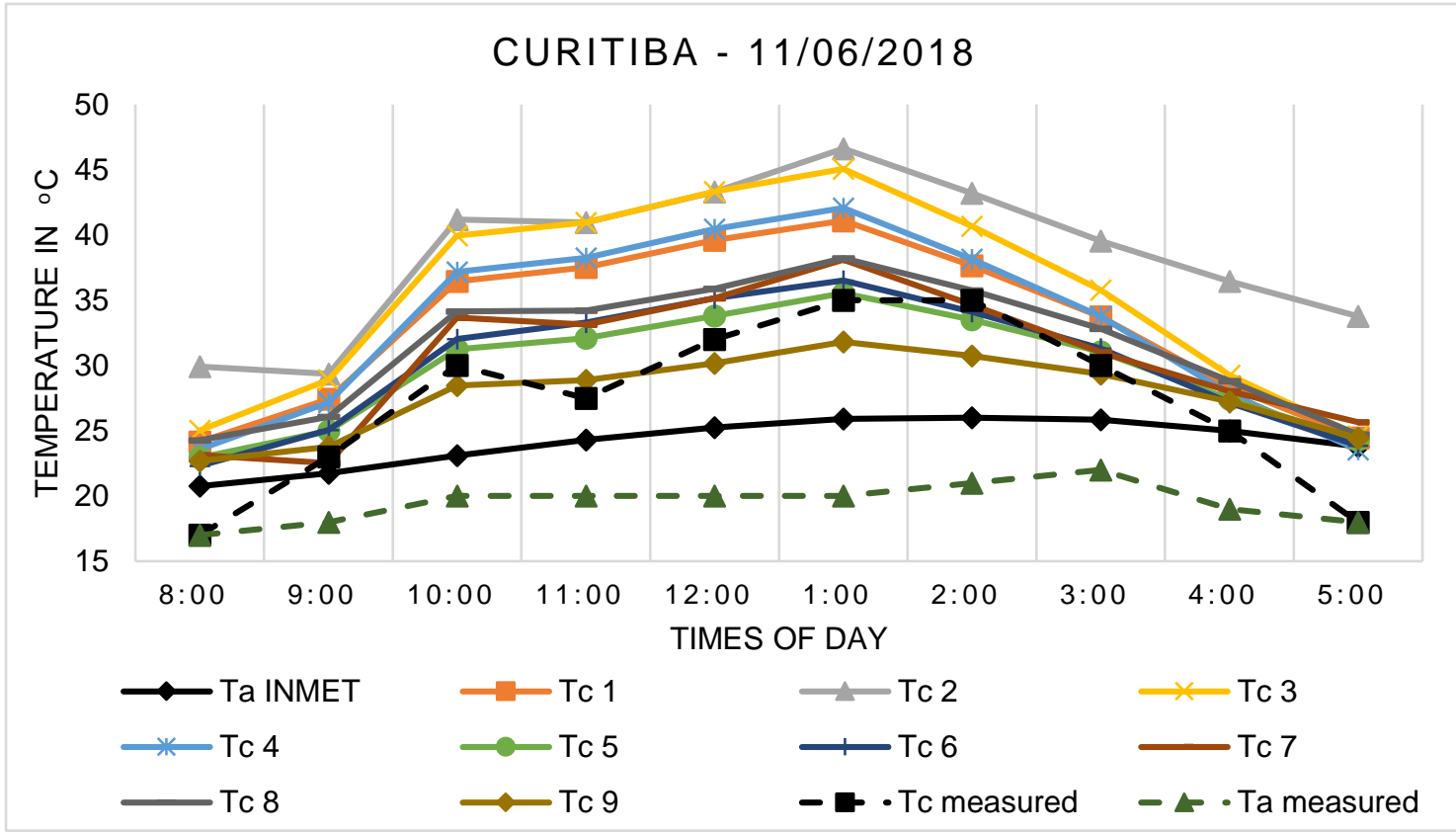

Figure 4. Comparison between calculated and measured $T c$ with $T a$.

When analyzing the measured values of $T c$, it is noted that this curve (dashed in black) presented, on average, lower values than those calculated by nine different methods. Looking at the graph, it can be seen that $T c 9$ was the curve that most approached the actual Tc. The shape of the curves in the chart reveals the passage of clouds around 11 o'clock, a fact that was actually verified in loco, causing slight decrease in Tc at that time. The dashed curve in green reveals the Ta measured with the multimeter, which was kept equal to or less than the Tc measured for this test.

All values calculated for June $11^{\text {th }} 2018$, in Curitiba for Tc, proposed by different researchers, were analyzed hourly and compared with the measured data. In this way, the 
hourly error was calculated, comparing the calculated data with the measured data, with also the mean error. It was observed that the equation proposed by [21], represented by Tc 9, presented the lowest mean error and the methodology proposed by [15], of Tc 2, the largest mean error.

Observing the average error estimates throughout the day, it was observed that at the beginning and end of the day ( $8 \mathrm{am}$ and $5 \mathrm{pm})$ the highest error values were found. On the other hand, the smallest errors, on average, are between $1 \mathrm{pm}$ and $3 \mathrm{pm}$, more precisely at 14 o'clock, when the smallest error is calculated for practically all the equations, except for the methodology used by [18], where greater precision occurred at $1 \mathrm{pm}$. Another conclusion in this study shows that the equations, $T c 1$ and $T c 4$, presented similar results, with a small variation in the hourly calculations for $T c$ and in the mean error. Finally, Table 3 shows the order of the studies in relation to the best modeling of the grid-connect PV system, used to perform the measurements of the temperature of the PV module with their respective mean calculated errors.

Table 3. Ranking of $T c$ equations with their average error.

\begin{tabular}{|c|c|c|c|}
\hline & & Authors & Average Error \\
\hline 10 & TC 9 & Duffie e Beckman (2013) & $5.20 \%$ \\
\hline $2^{\circ}$ & Tc 5 & Servant (1985) & $11.56 \%$ \\
\hline 3으 & Tc 6 & Lasnier e Ang (1990) & $12.51 \%$ \\
\hline $4^{0}$ & Tc 7 & Chenni et al. (2007) & $14.24 \%$ \\
\hline $5^{0}$ & Tc 8 & Skoplaki et al. (2008) & $17.98 \%$ \\
\hline $6^{\circ}$ & Tc 1 & Rauschenbach (1980) & $22.99 \%$ \\
\hline $7^{0} \underline{0}$ & Tc 4 & Schott (1985) & $23.01 \%$ \\
\hline $8^{\circ}$ & Tc 3 & Ross e Smokler (1986) & $30.87 \%$ \\
\hline 90 & Tc2 2 & Risser e Fuentes (1983) & $44.69 \%$ \\
\hline
\end{tabular}

The nine studied equation from the smaller to the highest average error.

\section{CONCLUSION}

When analyzing the hourly data for Curitiba, it was noticed that in the winter, the absolute values and the variation of the Tc are smaller when compared with the summer. Ta remains below $T c$ throughout the day in practically all situations and the highest values for Tc can be seen in the early afternoon. In the validation of the obtained results, it was noticed that the equation proposed by [21] was the one that best modeled the real system studied, presenting smaller average error between the calculation and the measured value.

Acknowledgments: The authors would like to thank UTFPR for the support and infrastructure available for the development of this research, and COPEL - Distribution for the support and funding of the resources for the realization of this R\&D project "ANEEL RD 2866-0464 / 2017 METHODOLOGY FOR ANALYSIS, MONITORING AND MANAGEMENT BY ENCOURAGED SOURCES".

\section{REFERENCES}

1. Pinho, J.; Galdino, M. Engineering manual for photovoltaic Systems. Rio de Janeiro: Cresesb Cepel; 2014. p. 66-101.

2. IEA. International energy agency. Snapshot of global photovoltaic markets, photovoltaic power systems programme. Report IEA PVPS T1-33:2018. Available online: http://www.iea-pvps.org/ (accessed on $14^{\text {th }}$ May 2018).

3. REN 21. Renewable energy policy network for the $21^{\text {st }}$ century. Renewables 2018 - Global Status Report (GSR), REN21 Secretariat, Paris, 2018.

4. National Electrical Energy Agency: Brazil generation capacity, generation information bank. Available online: http://www2.aneel.gov.br (accessed on 14th May 2018).

5. National Electrical Energy Agency: consumer units with distributed generation. Available online: http://www2.aneel.gov.br (accessed on 14th May 2018). 
6. Schwingshackl, C.; Petitta, M.; Wagner, J. E.; Belluardo, G.; Moser, D.; Castelli, M.; Zebisch, M.; Tetzlaff, A. Wind Effect on PV Module Temperature: Analysis of different techniques for an accurate estimation. EGUDivision 2013, volume 40, 1-564.

7. Deutsche Gesellschaft fur Sonnenenergie (DGS). Planning and Installing Photovoltaic Systems: A Guide for Installers, Architects, and Engineers. $2^{\text {nd }}$ ed.; Earthscan Publications Ltd, Berlin, Germany, 2007; 01-396.

8. Dubey, S.; Sarvaiya, J. N.; Seshadri, B. Temperature dependent photovoltaic (PV) efficiency and its effect on PV production in the world: a review. Energy Procedia 2012, volume 33, pp. 311321.

9. Akhsassi, M.; El Fathi, A.; Erraissi, N.; Aarich, N.; Bennouna, A.; Raoufi, M.; Outzourhit, A. Experimental investigation and modeling of the thermal behavior of a solar PV module. Solar Energy Materials and Solar Cells 2018, volume 180, pp. 271-279.

10. Koehl, M.; Heck, M.; Wiesmeier, S.; Wirth, J. Modeling of the nominal operating cell temperature based on outdoor weathering. Solar Energy Materials and Solar Cells 2011, volume 95, pp. 1638-1646.

11. Coskun, C.; Toygar, U.; Sarpdag, O.; Oktay, Z. Sensitivity analysis of implicit correlations for photovoltaic module temperature: a review. Journal of Cleaner Production 2017, volume 164, pp. 1474-1485.

12. Jakhrani, A. Q.; Othman, A. K.; Rigit, A. R. H.; Samo, S. R. Comparison of solar photovoltaic module temperature models. World Applied Science Journal 2011, volume 14, pp. 01-08.

13. Skoplaki, E.; Boudouvis, A.G.; Palyvos, J.A. A simple correlation for the operating temperature of photovoltaic modules of arbitrary mounting. Solar Energy Materials and Solar Cells 2008, volume 92, pp. 1393-1402.

14. Rauschenbach, H.S. Solar cell array design handbook, $1^{\text {st }}$ ed.; Van Nostrand Reinhold Company, New York, United States of America, 1980; pp: 390-391.

15. Risser, V.V.; Fuentes, M. K. Linear regression analysis of flat-plate photovoltaic system performance data. Photovoltaic Solar Energy Conference 1984, pp: 623-627.

16. Ross, R.G.; Smokler, M. I. Flat-Plate solar array project final report, Volume VI: Engineering Sciences and Reliability, Report DOE/JPL-1012-125; JPL: California, United States of America, 1986.

17. Schott, T. Operation temperatures of PV modules. Photovoltaic solar energy conference 1985, pp. 392-396.

18. Servant, J.M. Calculation of the cell temperature for photovoltaic modules from climatic data, ISES 1986, pp. 1640-1643.

19. Lasnier, F.; Ang, T. G. Photovoltaic engineering handbook, $1^{\text {st }}$ ed.; IOP Publishing LTD: Lasnier, France, 1990; pp. 258.

20. Chenni, R.; Makhlouf, M.; Kerbache, T.; Bouzid, A. A detailed modeling method for photovoltaic cells. Energy 2007, volume 32, pp. 1724-1730.

21. Duffie, J. A.; Beckman, W. A. Solar engineering of thermal processes. $4^{\text {th }}$ ed. Wiley: Madison, United States of America, 2013.

22. National Institute of Meteorology. Available online: http://www.inmet.gov.br (accessed on 16 July 2018).

23. Tiepolo, G; Pereira, E.; Urbanetz JR, J.; Pereira, S.; Gonçalves, A.; Lima, F.; Costa, R.; Alves, A. Solar Energy Atlas - Paraná, 1st ed.; National Space Research Institute: São José dos Campos, Brazil, 2017; pp. 10-84.

24. Souza, M. A.; Souza, J. P.; Pereima, A. T. Simplified methodology for calculating PV Module operating temperature under non-standard environmental conditions, IV Smart Energy 2017, pp. 01-06. 